Terakreditasi Sinta 3 | Volume 3 | Nomor 4 (Special Issue) | Tahun 2020| Halaman 423-434

P-ISSN 2615-725X | E-ISSN 2615-8655

http://diglosiaunmul.com/index.php/diglosia/article/view/129

\title{
PENGEMBANGAN BAHAN AJAR MENULIS CERITA PENDEK DENGAN MEDIA ADOBE FLASH
}

\author{
Development of Teaching Materials in Writing Short with Adobe Flash
}

\author{
Siti Subaidah ${ }^{1 *}$, Susilo $^{2}$, dan Mohammad Siddik ${ }^{3}$ \\ ${ }^{1}$ Magister Pendidikan Bahasa dan Sastra Indonesia FKIP Universitas Mulawarman \\ ${ }^{2,3}$ FKIP Universitas Mulawarman \\ 1,*Pos-el korespondensi: sitisubaidah645@gmail.com \\ ${ }^{2}$ Pos-el: olisusunmul@gmail.com \\ ${ }^{3}$ Pos-el: siddik_54@yahoo.com
}

\begin{abstract}
This development aims to develop teaching materials for writing short stories with adobe flash SMP Class $I X$. The scope of this development is limited only to planning, material and evaluation in the learning process. The method used in this research is Research and Development (R\&D), using a development research design using the Brog \& Gall model. Teaching material development results obtained material expert test results $82 \%$ were declared feasible, media expert test $86 \%$ were declared feasible, small group field test $80 \%$ declared good, a large group field test $82.3 \%$ was declared good. So overall the data obtained from the development of instructional materials with adobe flash media is declared feasible, teaching materials with adobe flash media are effective in increasing motivation, focus and responsiveness while the evaluation results provide increased student ability in writing short stories.
\end{abstract}

Keyword: writing short stories, teaching materials, adobe flash

\begin{abstract}
Abstrak: Pengembangan ini bertujuan untuk mengembangkan bahan ajar menulis cerpen dengan adobe flash SMP Kelas IX. Ruang lingkup pengembangan ini hanya terbatas pada perencanaan, materi dan evaluasi dalam proses pembelajaran. Metode yang digunakan dalam penelitian ini adalah Research and Development $(\mathrm{R} \& \mathrm{D})$, menggunakan desain penelitian pengembangan dengan model Brog \& Gall. Hasil pengembangan bahan ajar diperoleh hasil uji ahli materi $82 \%$ dinyatakan layak, uji ahli media $86 \%$ dinyatakan layak, uji lapangan kelompok kecil $80 \%$ dinyatakan baik, uji lapangan kelompok besar $82,3 \%$ dinyatakan baik. Jadi secara keseluruhan data yang diperoleh dari pengembangan bahan ajar dengan media adobe flash dinyatakan layak, bahan ajar dengan media adobe flash efektif dalam meningkatkan motivasi, fokus dan daya tanggap sedangkan hasil evaluasi memberikan peningkatan kemampuan siswa dalam menulis cerpen.
\end{abstract}

Kata kunci: menulis cerpen, baban ajar, adobe flash

\section{A. PENDAHULUAN}

Pembelajaran sastra berperan penting dalam mencapai aspek pendidikan, sosial, perasaan dan keagamaan, sikap, penilaian, keagamaan. Pembelajaran sastra diharapkan dapat membentuk siswa berbudi pekerti halus dan mengembangkan diri dari kegiatan belajar sastra di sekolah. Hal ini sejalan dengan Undang-Undang Sistem Pendidikan Nasional (2003, hal. 20) yang menyebutkan bahwa tujuan umum pembelajaran sastra adalah mewujud-kan suasana dan proses pembelajaran agar siswa secara aktif mengembangkan potensi dirinya untuk memiliki kekuatan spiritual keagamaan, pengendalian diri, kepribadian, kecerdasan, akhlak mulia, 
serta ketrampilan yang diperlukan dirinya, masyarakat, bangsa, dan negara.

Pembelajaran sastra merupakan suatu cara belajar dengan menikmati dan memanfaatkan karya sastra untuk memperluas wawasan, memperluas budi pekerti, serta meningkatkan pengetahuan dan kemampuan berbahasa. Selain itu siswa juga diajarkan untuk menghargai dan membangga-kan sastra Indonesia sebagai khazanah budaya dan intelektual manusia Indonesia. Pembelajaran sastra di sekolah tentunya sangat relevan sekali sebagi media untuk memanipulasi pembentukan karakter siswa. Hal ini juga sejalan dengan tujuan kurikulum 2013 yang lebih menekankan pada pembentukan sikap. Pembentukan sikap hanya akan terjangkau dengan adanya pendekatan transfer budaya atau seni. Sebagai mana kita ketahui bahwa sastra merupakan salah satu aspek seni yang mengandung refleksi kehidupan, amanat dan nilai-nilai sosial bahkan terkait langsung dengan budaya dan kearifan lokal setempat.

Berbagai problematika dalam proses pembelajaran sastra masih sering ditemui. Salah satu diantaranya adalah kurangnya sarana yang menyediakan referensi yang berkaitan dengan pembelajaran sastra seperti buku penunjang dan perpustakaan. Selain itu, kurangnya sikap apresiatif siswa terhadap pembelajaran sastra juga menyebabkan pembelajaran sastra sering diabaikan. Hal ini menyebabkan pembelajaran sastra mendapat status yang kurang menggembirakan dalam pembelajaran di sekolah. Berbagai hambatan tersebut seharusnya dapat dimanipulasi oleh guru dengan menggunakan media pembelajar-an sebagai pendukung pembelajar-an sastra. Penyusunan media pembelajaran yang tepat dan sesuai dengan kebutuhan dan minat siswa tentunya akan memberikan dampak positif untuk meningkatkan gairah belajar siswa.

Kemendiknas (2011, hal. 59) menyatakan bahwa penyajian pembelajaran sastra hanya sekedar memenuhi tuntunan kurikulum akan terasa kering atau kurang hidup, dan cenderung kurang mendapat tempat di hati siswa. Padahal pembelajaran bahasa dan sastra Indonesia memiliki peran sentral dalam perkembangan kecerdasan, intelektual, sosial, dan emosional. Melalui pembelajaran bahasa dan sastra Indonesia, siswa diharapkan dapat mengenal diri dan budayanya serta budaya orang lain, mampu mengemukakan gagasan dan perasaan, mampu berpartisipasi dalam masyarakat, serta mampu menggunakan kemampuan berpikir analitis dan imajinatif dalam kehidupan sehari-harinya (Depdiknas, 2006, hal. 6).

Kunci keberhasillan pembelajaran sastra terletak pada cara dan upaya guru dalam mengelola dan menyampaikan pembelajaran sastra. Guru bahasa dan sastra Indonesia hendaknya mampu memotivasi dan meng-akrabkan siswa dengan karya siswa. Siswa bukan sekedar memahami teori sastra, siswa lebih dituntut untuk memiliki kemampuan dalam mengapresiasi karya sastra dan menciptakan karya sastra yang bermutu. Selain itu guru dalam menyampaikan materi pembelajaran sastra harus menarik, tidak monoton sehingga berkenan dihati siswa.

Aminuddin (2011, hal. 5) menyatakan bahwa upaya pemahaman unsur-unsur dalam bacaan sastra tidak dapat dilepaskan dari masalah menulis. Tarigan (2008, hal. 3) menyatakan bahwa menulis merupakan suatu kegiatan yang produktif dan ekspresif. Kegiatan menulis cerpen akan membantu siswa dalam memahami unsur-unsur cerita. Selain itu dengan menulis siswa dapat mengembangkan berbagai ilmu atau pengetahuan yang dimiliki dalam sebuah tulisan, baik dalam bentuk cerpen, artikel, laporan ilmiah, cerpen, puisi, dan sebagainya. Pada prinsipnya fungsi utama dari tulisan adalah sebagai alat komunikasi secara tidak langsung. 
Salah satu pembelajaran sastra sebagai salah satu kompetensi dasar yang harus dikuasai oleh siswa adalah cerpen. Cerita pendek biasanya mempunyai kata yang kurang dari 10.000 kata atau kurang dari 10 halaman saja. Selain itu, cerpen atau cerita pendek hanya memberikan sebuah kesan tunggal yang demikian serta memusatkan diri pada salah satu tokoh dan hanya satu situasi saja. Berdasarkan pengertian-pengertian di atas tentunya cerpen memiliki ciri-ciri secara khusus. Ciri-ciri cerpen menurut Morris adalah (a) ciri-ciri utama cerita pendek adalah singkat, padu, dan intensif (brevity, unity, and intensity); (b) unsur-unsur cerita pendek adalah adegan, toko, dan gerak (scena, character, and action); dan (c) bahasa cerita pendek harus tajam, sugestif, dan menarik perhatian (incicive, suggestive, and alert) (Tarigan, 2008, hal. 21).

Kosasih (2014, hal. 113) menjelaskan tentang struktur cerita pendek secara umum dibentuk oleh abstrak, orientasi, komplikasi, evaluasi, resolusi, dan koda. Abstrak (sinopsis) merupakan bagian cerita yang menggambarkan keseluruhan isi cerita. Orientasi atau pengenalan cerita, baik itu berkenaan dengan penokohan ataupun bibit-bibit masalah yang dialaminya. Komplikasi atau puncak konflik, yakni bagian cerpen yang menceritakan puncak masalah yang dialami tokoh utama. Evaluasi yakni bagian yang menyatakan komentar pengarang atas peristiwa puncak yang telah diceritakannya. Resolusi merupakan tahap penyelesaian akhir dari seluruh rangkaian cerita. Koda merupakan komentar akhir terhadap keseluruhan isi cerita, mungkin juga diisi dengan kesimpulan tentang hal-hal yang dialami tokoh utama kemudian.

Pembelajaran sastra menulis cerpen di sekolah juga mengalami banyak masalah. Studi pendahuluan yang dilakukan peneliti dengan melakukan diskusi dengan guru mata pelajaran Bahasa Indonesia di SMP Negeri 3 Balikpapan menunjukkan bahwa perlu adanya peran guru dalam menyusun bahan ajar menulis cerpen. Penyusunan bahan ajar ini tentunya bisa memberikan dukungan kepada siswa agar lebih memahami materi pembelajaran menulis cerpen tersebut. Selanjutnya berdasarkan pengamatan lapangan menunjukkan bahwa dalam pembelajaran menulis cerpen, siswa masih kesulitan dalam menulis, menentukan tema, menyusun kosa kata dan lain-lain.

Menurut Widodo \& Jasmadi, bahan ajar adalah seperangkat sarana atau alat pembelajaran yang berisikan materi pembelajaran, metode, batasan-batasan, dan cara mengevaluasi yang didesain secara sistematis dan menarik dalam rangka mencapai tujuan yang diharapkan, yaitu mencapai kompetensi atau subkompetensi dengan segala kompleksitasnya (Lestari, 2013, hal. 1). Bahan ajar adalah segala bentuk bahan yang digunakan untuk membantu guru/instruktor dalam melaksanakan kegiatan belajar mengajar di kelas. Bahan yang dimaksud bisa berupa bahan tertulis maupun bahan tidak tertulis. (National Center for Vocational Education Research Ltd/National Center for Competency Based Training). Pengertian ini menjelaskan bahwa suatu bahan ajar haruslah dirancang dan ditulis dengan kaidah intruksional karena akan digunakan oleh guru untuk membantu dan menunjang proses pembelajaran.

Bahan ajar memiliki peranan yang sangat penting dalam kegiatan pembelajaran. Bahan ajar berfungsi untuk mengarahkan semua aktivitas guru dan siswa pada subtansi kompetensi dalam proses pembelajaran. Selain itu tentunya bahan ajar juga berfungsi sebagai alat bantu untuk mendapatkan pemahaman dalam mencapai evaluasi hasil pembelajaran. Menurut Prastowo, bahan ajar yang baik sekurang-kurangnya mencakup petunjuk belajar, kompetensi yang akan dicapai, isi pelajaran, informasi pendukung, latihan-latihan, petunjuk 
kerja, evaluasi dan respons terhadap hasil evaluasi (Lestari, 2013).

Kehadiran bahan ajar akan membantu siswa dalam proses pembelajaran. Hal ini karena bahan ajar dapat dipelajari sesuai dengan kemampuan yang dimiliki oleh siswa. Namun, penyusunan bahan ajar juga harus dikembangkan dengan menggunakan media pembelajaran yang tepat. Kemampuan guru dalam memvariasi model dan media pembelajaran yang rendah dalam penyusunan bahan ajar akan membuat bahan ajar tersebut kurang efektif digunakan. Sebaiknya, pengembangan bahan ajar dengan media pembelajaran yang tepat akan mampu membangkitkan minat dan gairah siswa.

Asyhar (2011:8) megemukakan bahwa media pembelajaran dapat dipahami sebagai 'segala sesuatu' yang dapat menyampaikan atau menyalurkan pesan dari suatu sumber secara terencana sehingga terjadi lingkungan belajar yang kondusif. Lingkungan belajar yang kondusif adalah suatu kondisi pembelajarn antara media dan penerimanya dapat melakukan proses belajar secara efisien dan efektif. Pemilihan media yang baik juga akan mengaktifkan pembelajar dalam memberikan tanggapan, umpan balik, dan juga mendorong oleh pembelajar untuk melakukan praktik-praktik dengan benar (Novian, 2005:64). Musfiqon (2012:30) mengemuka-kan ciri-ciri media pembelajaran sebagai berikut (1) semua jenis alat yang dimanfaatkan sebagai alat bantu pembelajaran, (2) menumbuhkan minat belajar siswa, (3) meningkatkan kualitas pembelajaran, dan (4) menudahkan komunikasi antara guru dan siswa dalam pembelajaran.

Musfiqon (2012:28) juga berpendapat bahwa media pembelajaran berfungsi sebagai sebagai penjelas pesan pengajar atau guru. Derek Rowntree (dalam Rohani, 1997:7-8) memaparkan media pembelajaran berfungsi membangkitkan motivasi belajar, mengulang apa yang telah dipelajari, menyediakan stimulus belajar, mengaktifkan respons peserta didik, memberikan balikan dengan segera dan menggalakkan latihan yang serasi. Hal ini menunjukkan bahwa media merupakan alat bantu mengajar, termasuk salah satu komponen lingkungan belajar yang dirancang oleh pembelajar. Media pembelajaran juga memiliki fungsi untuk meningkatkan keinginan dan memberikan rangsangan kepada siswa untuk belajar.

Hamalik dalam Arsyad (2003:15) mengemukakan bahwa pemakaian media dalam proses belajar mengajar dapat membangkitkan keinginan dan minat yang baru, membangkitkan motivasi dan rangsang-an kegiatan belajar, dan bahkan membawa pengaruh-pengaruh psikologis terhadap siswa. Penggunaan media pembelajaran pada tahap orientasi pembelajaran akan sangat membantu keefektifan proses pembalajaran dan penyampaian pesan dan isi pelajaran pada saat itu. Disamping membangkitkan motivasi dan minat siswa, media pembelajaran juga dapat membantu siswa menigkatkan pemahaman, menyajikan data dengan menarik dan ter-percaya, memudahkan penafsiran data dan memadatkan informasi. Paparan Hamalik di atas menekankan bahwa penggunaan media pembelajaran dalam kegiatan belajar mengajar dapat meningkatkan motivasi dan keinginan belajar siswa serta siswa dapat tertarik dan lebih mudah memahami materi yang disampaikan.

Penting bagi seorang pengajar atau guru mengetahui manfaat penyusunan media pembelajaran. Menurut Latuheru (1988: 23) manfaat media pembelajaran yaitu: 1) media pembelajaran dapat menarik dan memperbesar perhatian anak-anak didik terhadap materi pengajaran yang disajikan. 2) media pembelajaran mengurangi, bahkan dapat menghilangkan adanya verbalisme. 3) media pembelajaran mengatasi perbedaan pengalaman belajar berdasarkan latar 
belakang sosio ekonomi dari anak didik. 4) media pembelajaran membantu memberikan pengalaman belajar yang sulit diperoleh dengan cara yang lain. 5) media pembelajaran dapat mengatasi masalah batas-batas ruang dan waktu. 6) media pembelajaran dapat membantu perkembangan pikiran anakdidik secara teratur tentang hal yang mereka alami. 7) media pembelajaran dapat membantu anak didik dalam mengatasi hal yang sulit nampak dengan mata. 8) media pembelajaran dapat menumbuhkan kemampuan berusaha sendiri berdasarkan pengalaman dan kenyataan. 9) media pembelajaran dapat mengatasi al/peristiwa/kejadian yang sulit diikuti oleh indera mata, 10) media pembelajaran memungkinkan terjadinya kontak langsung antara anak didik, guru, dengan masyarakat, maupun dengan lingkungan alam di sekitar mereka. Manfaat media pembelajaran menurut Manfaat penggunaan media pembelajaran tersebut tentunya memerlukan kreatifitas guru dalam mendesain media pembelajaran tersebut sehingga dapat memenuhi kebutuhan dalam mencapai kompetensi pembelajaran.

Jenis-jenis Media Media pembelajaran menurut taksonomi leshin, dkk (dalam arsyad, 2003:79-101) adalah sebagai berikut, (1) media berbasis manusia, (2) media berbasis cetakan, (3) media berbasis visual, (4) media berbasis audiovisual, (5) media berbasis komputer. Media berbasis manusia merupakan media yang digunakan untuk mengirim dan mengkomunikasikan peran atau informasi. Media pembelajaran berbasis cetakan yang paling umum dikenal adalah buku teks, buku penuntun, buku kerja atau latihan, jurnal, majalah, dan lembar lepas. media berbasis visual (image) dalam hal ini memegang peranan yang sangat penting dalam proses belajar. Media visual dapat memperlancar pemahaman dan memperkuat ingatan. visual dapat pula menumbuhkan minat siswa dan dapat memberikan hubungan antara isi materi pelajaran dengan dunia nyata. Media audiovisual yang menggabungkan pengguna-an suara memerlukan pekerjaan tambahan untuk memproduksinya. salah satu pekerjaan penting yang diperlukan dalam media audio-visual adalah penulisan naskah dan storyboard yang memerlukan persiapan yang banyak, rancangan dan penelitian. Media berbasis komputer adalah sarana komputer dimanfaatkan perannya sebagai manajer dalam proses pembelajaran yang dikenal dengan nama Computer Managed Instruction (CMI). Namun, pemanfaatan media komputer ini masih memerlukan software (perangkat lunak)t ambahan yang dapat dipilih dan disesuaikan dengan kegiatan pembelajaran yang dilakukan.

Hidayatullah

mengemukakan ada banyak perangkat lunak yang dapat membantu dalam proses pembelajaran. Perangkat lunak tersebut dapat berupa Microsoft Power Point. Microsoft Power Point merupakan perangkat lunak yang dapat digunakan untuk presentasi. Namun dalam pengembangan bahan ajar ini perangkat lunak media pembelajaran yang digunakan berbasis educational animation (pembelajaran berbasis animasi). Educational animation yaitu visualisasi materi pelajaran dalam bentuk animasi untuk digunakan dalam pembelajaran.

Salah satu program perangkat lunak yang dapat menunjang educational animation tersebut adalah software adobe flash. adobe flash merupakan program yang dimedia khusus oleh Adobe program standar authoring tool professional yang digunakan untuk membuat animasi dan bitmap yang sangat menarik untuk situs web, CD interaktif, dan lainnya. Adobe Flash memiliki kemampuan untuk membuat animasi dua dimensi yang handal dan ringan, logo, GIF, game, dan lainnya. Software Adobe Flash ini bersifat dinamis untuk memvisualisasikan animasi sehingga diharapkan dapat mendukung 
pembuatan media pembelajaran yang menarik.

Dikse (2010, hal. 1) berpendapat bahwa adobe flash dibuat untuk keperluan membuat suatu aplikasi web yang interaktif dan menarik. Adobe flash sering digunakan untuk membuat animasi dan untuk keperluan lain seperti membuat game dan tutorial. Adobe flash juga dapat menampilkan teks, gambar, animasi, dan audio secara bersama. Berdasarkan sifatnya tersebut, maka sangat mungkin apabila adobe flash digunakan sebagai sarana pengembangan media pembelajaran. Litbang Wahana Komputer (2006, hal. 1) mengemukakan bahwa adobe flash merupakan aplikasi animasi yang berjalan dengan sistem operasi Windows. Pembuatan suatu program maka dibutuhkan aplikasi lain untuk menambahkan animasi, gambar, video maupun suara.

Beberapa penelitian yang relevan dengan penelitian ini antara lain yang dilakukan Sugiyono (2014) "Pengembangan Bahan Ajar Menyimak Berbasis Multimedia Interaktif dalam Model Belajar Mandiri untuk Sekolah Menengah Pertama". Sugiyono (2014) dalam penelitian pengembangan yang dilakukannya bertujuan untuk mengembang-kan bahan ajar yang diharapkan meningkatkan kualitas pembelajaran dengan bantuan media pembelajaran yang relevan pada materi menyimak pada pelajaran Bahasa Indonesia. Hasil angket kebutuhan siswa dan kebutuhan guru yang dominan tertarik dengan media yang berbasis multimedia interaktif sebagai upaya meningkatkan kualitas dan hasil belajar pembelajaran bahasa Indonesia.

Ernawati (2012) dalam penelitiannya mengembangkan media pembelajaran kuis interaktif berbasis adobe flash 8.0 mata pelajaran kimia SMP/MA, kelas XI semester genap yang dipakai sebagai sumber belajar mandiri asam basa. Penelitian ini dengan model procedural.
Prosedur dalam penelitian ini terdiri atas empat tahap yaitu tahap perencanaan, pengorgansasian, pelaksanaan, dan penilaian produk.

Perbedaan penelitian pengembangan ini dengan penelitian yang terdahulu adalah (1) penelitian terdahulu pengembangan bahan ajar dengan media interaktif pada materi menyimak dengan media interaktif, sedangkan untuk peneltian sekarang mengembangkan bahan ajar dengan media adobe flash pada materi menulis cerpen, dan (2) penelitian terdahulu pengembangan media pembelajaran kimia sedangkan peneltian sekarang mengembangkan bahan ajar dengan media adobe flash pada materi menulis cerpen pada pelajaran bahasa indonesia. Berdasarkan penelitian terdahulu yang menggunakan adobe flash untuk pengembangan media, hasil penelitian menunjukkan bahwa program adobe flash dapat digunakan untuk mengembangkan media pembelajaran yang layak digunakan dalam pembelajaran dan dapat meningkatkan hasil belajar.

Berdasarkan uraian tersebut, perlu sebuah solusi untuk pembelajaran menulis cerpen yaitu dengan pengembangan bahan ajar menulis cerpen yang dikombinasikan dengan media adobe flash. Pengembanhan bahan ajar menulis cerpen dengan media adobe flash tentunya akan menjadi alternatif penunjang pembelajaran yang inovatif untuk membantu membangkitkan apresiasi dan imajinasi siswa terhadap pembelajaran menulis cerpen. Adapun tujuan penelitian pengembangan bahan ajar menulis cerpen dengan media adobe flash ini adalah untuk (1) mendeskripsikan kualitas bahan ajar menulis cerpen dengan media adobe flash untuk siswa SMP kelas IX, (2) mendeskripsikan kevalidan bahan ajar menulis cerpen dengan media adobe flash untuk siswa SMP kelas IX, (3) mendeskripsikan kepraktisan bahan ajar menulis cerpen dengan media adobe flash untuk siswa SMP kelas IX, dan (4) mendeskripsikan keefektifan bahan ajar 
menulis cerpen dengan media adobe flash untuk siswa SMP kelas IX.

Pengembangan bahan ajar menggunakan media pembelajaran adobe flash dalam pembelajaran sastra dapat menciptakan situasi pembelajaran yang berkualitas dan diharapkan mampu membangkitkan sikap positif siswa untuk menelaah penulisan cerpen. Selain itu, bahan ajar yang dikembangkan dengan media pembelajaran adobe flash, diharapkan dapat memvisualisasikan materi menulis cerpen dengan lebih menarik dan menyenangkan untuk siswa. Pengembangan bahan ajar menggunakan media pembelajaran adobe flash dalam pembelajaran sastra dapat memvisualisasikan gambar, animasi, dan suara sehingga diharapkan dapat membuat siswa semakin berani berapresiasi dan berimajinasi dalam menulis cerpen.

\section{B. METODE}

Pengembangan bahan ajar menulis cerita pendek dengan media adobe flash ini menggunakan metode penelitian dan pengembangan. Menurut Sugiyono (2009, hal. 297), penelitian pengembangan atau research and development (R\&D) adalah aktifitas riset dasar untuk mendapatkan informasi kebutuhan pengguna (needs assessment), kemudian dilanjutkan kegiatan pengembangan untuk menghasilkan produk dan mengkaji keefektif-an produk tersebut. Metode penelitian ini berbeda dengan penelitian lainnya karena bertujuan mengembangkan produk berdasar-kan uji coba untuk kemudian direvisi sampai menghasilkan produk yang layak pakai.

Model pengembangan yang digunakan dalam penelitian pengembangan bahan ajar dengan media adobe flash ini adalah model pengembangan adaptasi R\&D dalam Borg \& Gall (1983, hal. 772). Model pengembangan ini terdiri dari sepuluh langkah, yaitu (1) pengumpulan informasi, (2) perencanaan, (3) pengembangan format produk awal, (4) uji coba lapangan awal, (5) revisi hasil uji coba produk, (6) uji coba lapangan, (7) penyemurnaan produk hasil uji lapangan, (8) uji pelaksanaan lapangan, (9) penyempurnaan produk akhir, dan (10) diseminasi dan distribusi.

Tempat kegiatan penelitian dan pengembangan bahan ajar menulis cerpen dengan media adobe flash ini di SMPN 3 Balikpapan yang beralamat di Jl. Soekarno Hatta KM.1, No.5, Muara Rapak, Kecamatan Balikpapan Utara, Kota Balikpapan, Kalimantan Timur 76125. Waktu penelitian ini dilakukan sejak tanggal 29 September s.d. Desember 2019. Adapun subjek uji coba kegitan penelitian dan pengembangan bahan ajar menulis cerpen dengan media adobe flash ini adalah siswa kelas IX. Jumlah sampel dalam uji coba kelompok kecil sebanyak 5 siswa dan jumlah sampel dalam uji coba kelompok besar sebanyak 10 siswa.

Instrumen pengumpulan data yang digunakan dalam proses uji coba pengembangan bahan ajar dengan media adobe flash ini adalah: (a) angket/kuisioner, (b) observasi, (c) diskusi, (d) dokumentasi, (e) konsultasi, (f) wawancara. Pengumpulan data untuk telaah ahli isi dan ahli media pembelajaran dengan menggunakan angket, diskusi dan konsultasi, sedangkan pengumpul-an data dari uji coba kelompok kecil dan uji coba lapangan menggunakan: (a) angket, (b) diskusi, (c) observasi, dan (d) wawancara. Kuesioner adalah sejumlah pertanyaan tertulis yang digunakan untuk memperoleh informasi dari responden dalam arti laporan tentang pribadinya atau hal-hal yang diketahui (Arikunto, 2006, hal. 151). Isi dari kuesioner meliputi form penilaian untuk ahli/pakar dan juga from penilaian untuk siswa.

Instrumen kelayakan bahan ajar dengan media adobe flash menggunakan skala Likert dengan alternatif jawaban sangat baik, baik, cukup, kurang dan sangat kurang. Supaya diperoleh data kuantitatif maka alternatif jawaban diberi skor, yakni sangat baik (skor 5), baik 
(skor 4), cukup (skor 3), kurang (skor 2), dan sangat kurang (skor 1). Saran dan komentar dalam formulir digunakan sebagai petunjuk tindak lanjut untuk merevisi produk pengembangan bahan ajar menulis cerpen dengan media Adobe Flash.

\section{PEMBAHASAN}

Tahap I pengumpulan informasi dilakukan peneliti dengan cara menggali informasi awal mengenai kondisi di SMP Negeri 3 Balikpapan. Pendidik mata pelajaran bahasa Indonesia di SMP Negeri 3 Balikpapan empat orang dan semuanya berlatar belakang pendidikan sarjana, berasal dari Perguruan Tinggi Negeri dan Swasta. Rata-rata kelima orang pendidik tersebut memiliki latar belakang pendidikan S1.

Selanjutnya peneliti melakukan observasi dan wawancara dengan pendidik dan peserta didik di SMP Negeri 3 Balikpapan. Hasil observasi dan wawancara menunjukkan bahwa siswa memiliki kecenderungan minat beragam dalam pembelajaran menulis cerpen. Kurangnya inovasi dalam kegiatan pembelajaran menulis cerpen menjadi salah satu hambatan dalam meningkatkan motivasi belajar siswa. Rata-rata para pendidik dalam mengajar menggunakan model konvensional. Hal ini disebabkan oleh karena terlalu berat tuntutan pemerintah dalam penjabaran silabus.

Tahap II perencanaan dilakukan melalui dua kegiatan yaitu perencanaan atau desain produk dan pengembangan produk. Tahap desain produk meliputi kegiatan menentukan komponen bahan ajar dengan media adobe flash. Komponenkomponen tersebut meliputi konsep penyampaian dan pengorganisasian materi, jenis tugas yang diberikan, soal evaluasi, gambar, artikel, contoh-contoh, serta layout bahan ajar.

Tahap III pengembangan format produk awal bahan ajar menulis cerpen dengan media adobe flash terdiri dari penyusunan 5 komponen. Komponen pengembangan yang disusun meliputi komponen tujuan pem-belajaran, materi pembelajaran, kegiatan pembelajaran, media dan sumber belajar dan komponen evaluasi pembelajaran. Tahap ini akan menghasilkan desain produk awal berupa bahan ajar dengan media adobe flash yang sebelumnya telah dilakukan penyusunan instrumen penilaian produk untuk dijadikan pedoman dalam mendesain produk.

Tahap IV uji coba awal produk bahan ajar menulis cerpen dengan media adobe flash dilakukan untuk memperoleh informasi mengenai bagian-bagian yang perlu mendapatkan perhatian untuk dilakukan perbaikan atau revisi. Peneliti melakukan beberapa kegiatan pada tahap ini, yaitu tahap pra validasi melalui dosen pembimbing, tahap validasi melalui uji ahli materi dan uji ahli media. Hasil penilaian uji coba produk awal menunjukkan bahwa dari segi efektifitas produk layak untuk diimplemantasikan. Hasil penilaian dari segi efesiensi produk juga mendapatkan penilaian layak untuk diimplementasikan. Sedangkan berdasarkan hasil penilaian dari segi tampilan dan daya taik masih kurang layak diimplementasikan sehingga perlu mendapat perhatian untuk direvisi atau diperbaiki.

Tahap V revisi hasil uji coba produk bahan ajar menulis cerpen dengan media adobe flash dilakukan dengan cara melakukan perbaikan produk pengambangan berdasarkan saarn dan komenttar dari hasil uji ahli materi dan hasil uji ahli media. Fokus peneliti dalam melakukan revisi hasil uji coba produk ini adalah pada desain tampilan dan daya Tarik produk yang masih mendapatkan tanggapan kurang layak. Hasil revisi dikonsultasikan kembali dengan ahli materi dan ahli media sehingga pengembangan produk dikatakan layak untuk diuji cobakan. Hasil validasi ahli materi mendapatkan nilai $82 \%$ termasuk dalam katagori baik dan layak untuk 
digunakan. Hasil validasi uji ahli media diperoleh nilai $86 \%$ termasuk dalam katagori sangat baik dan layak digunakan

Tahap VI uji coba lapangan produk dengan melakukan proses implementasi langsung pada subjek dalam kelompok kecil. Hasil uji coba dalam kelompok kecil ini dimaksudkan agar peneliti memperoleh tanggapan dari siswa mengenai produk bahan ajar menulis cerpen dengan media adobe flash. Hasil uji coba produk dalam kelompok kecil ini akan dijadikan dasar dalam penyempurna-an produk.

Tahap VII penyempurnaan produk hasil uji lapangan ini dilakukan dengan cara mereview kembali produk hasil pengembang-an berdasarkan hasil uji kelompok kecil. Hasil uji lapangan kelompok kecil menunjukkan respons siswa terhadap produk diperoleh nilai 80\% termasuk dalam katagori baik. Namun terdapat beberapa komentar atau saran yang dijadikan peneliti sebagai masukan untuk menyempurnakan produk.

Tahap VIII uji pelaksanaan lapangan dilakukan dengan caran melkukan kegiatan uji coba dalam kelompok besar. Uji coba ini merupakan implementasi langsung produk pengembangan dengan subjek uji coba yang lebih banyak. Tujuannya adalah untuk mendapatkan respons yang lebih besar lagi untuk menjadikan produk pengembangan benar-benar layak digunakan dalam kegiatan pembelajaran. Hasil uji coba kelompok besar untuk respons siswa diperoleh nilai 82,3\% termasuk dalam katagori baik.

Tahap IX penyempurnaan produk akhir dilakukan peneliti dengan cara mereview kembali produk pengembangan bahan ajar menulis cerpen dengan media adobe flash berdasarkan tanggapan siswa yang menjadi subjek dalam uji coba kelompok besar. Peneliti juga melakukan pengkoreksian hasil evaluasi siswa dalam subjek uji coba kelompok besar. Hasil evaluasi belajar siswa dengan menggunakan produk bahan ajar menulis cerpen dengan media adobe flash menunjukkan bahwa pada aspek keaslian penulisan rata-rata adalah 77,9 (baik), aspek kesesuaian isi dengan judul rata-rata adalah 77,1 (baik), aspek keruntutan teks rata-rata adalah 81,4 (baik), aspek pilihan kosa kata rata-rata adalah 77,9 (baik), aspek pilihan tata bahasa rata-rata adalah 72,9 (baik), aspek penulisan kosa kata ratarata adalah 72,9 (baik), kerapihan tulisan rata-rata adalah 81,4 (baik), sesuai dengan Tabel 1.

Pengembangan bahan ajar menulis cerpen dengan media adobe flash pada peserta didik SMP kelas IX telah melalui berbagai macam tahapan penelitian dan pengembangan. Hal ini dilakukan sesuai tujuan pengembangan yaitu untuk menghasilkan bahan ajar menulis cerpen dengan media adobe flash yang memiliki validitas untuk pembelajaran. Validitas produk pengembangan bahan ajar menulis cerpen dengan media adobe flash berdasarkan dari isi, penyajian, bahasa dan kegrafikan, menghasilkan bahan ajar menulis cerpen dengan media adobe flash layak digunakan dalam kegitan pembelajaran bahasa Indonesia dan memberikan hasil belajar yang efektif. Selain itu hasil respons siswa dan guru terhadap produk pengembangan bahan ajar menulis cerpen dengan media adobe flash juga baik.

Pengembangan bahan ajar menulis cerpen dengan media adobe flash dilakukan pengujian oleh ahli materi dan ahli media. Validasi pengujian dilihat berdasarkan dari isi, penyajian, bahasa dan kegrafikan, menghasilkan bahan ajar menulis cerpen dengan media adobe flash dan memberikan hasil belajar yang efektif. Tujuan pengembangan bahan ajar ini yaitu untuk menghasilkan bahan ajar menulis cerpen yang memiliki validitas untuk pembelajaran dilihat dari isi, penyajian, bahasa dan kegrafikan. Pengembangan bahan ajar ini juga diharapkan dapat memberikan hasil belajar yang efektif. 
Tabel 1. Hasil Uji Ahli Materi dan Media

\begin{tabular}{lcc}
\hline Aspek Uji & Persentase & Kategori \\
\hline Aspek keaslian penulisan & $77,9 \%$ & Baik \\
Aspek kesesuaian isi & $77,1 \%$ & Baik \\
Aspek keruntutan teks & $81,4 \%$ & Baik \\
Aspek pilihan kosakata & $77,9 \%$ & Baik \\
Aspek pilihan tata bahasa & $72,9 \%$ & Baik \\
Aspek penulisan kosakata & $72,9 \%$ & Baik \\
Aspek kerapihan tulisan & $81,4 \%$ & Baik \\
\hline
\end{tabular}

Validitas uji lapangan dilakukan dengan memberikan angket kepada siswa mengenai bahan ajar menulis cerpen dengan media adobe flash dan wawancara terhadap guru bidang studi bahasa Indonesia. Hasil pengujian melalui respons siswa pada kelompok kecil yang terdiri dari 5 orang diperoleh nilai 72,3\% termasuk dalam katagori cukup dimana nilai bahasa adalah yang tertinggi yaitu $77 \%$. Setelah dilakukan perbaikan atas saran yang disampaikan kemudian dilakukan uji kelompok besar yang terdiri dari 10 orang siswa dan diperoleh nilai 79,6\% yang termasuk dalam katagori baik dimana aspek materi adalah yang tertinggi, yaitu $80 \%$. Hasil wawancara terhadap guru bidang studi bahasa Indonesia diperoleh hasil bahwa bahan ajar menulis cerpen dengan media adobe flash dapat digunakan dan layak karena memenuhi kebutuhan siswa.

Berdasarkan hasil tersebut dapat diketahui bahwa pengembangan bahan ajar menulis cerpen dengan media adobe flash pada peserta didik SMP kelas IX memiliki validitas untuk pembelajaran yang baik dan layak untuk digunakan. Selain itu penilaian respons siswa terhadap bahan ajar pembelajar-an baik demikian juga respons guru terhadap buku petunjuk guru juga baik.

\section{PENUTUP}

Pengembangan bahan ajar menulis cerpen dengan media adobe flash pada siswa kelas IX SMP dimulai dari studi pendahuluan, observasi di lapangan dan mengidentifikasi kebutuhan siswa. Pengembangan bahan ajar menulis cerpen dengan media adobe flash dibuat menggunakan silabus yang sudah dimodifikasi, RPP yang disesuaikan dengan kegiatan pembelajaran, materi, lembar kegiatan siswa yang dibuat melalui tahapan pendahuluan dengan mengidentifikasi kompetensi dasar, pengembangan perangkat dan instrument evaluasi.

Kualitas bahan ajar menulis cerpen dengan media adobe flash untuk siswa SMP kelas IX adalah (1) bahan ajar menulis cerpen dengan media adobe flash untuk siswa SMP kelas IX layak digunakan sebagai bahan ajar menulis cerpen dalam pembelajaran bahasa Indonesia berdasarkan uji ahli materi dan uji media; (2) bahan ajar menulis cerpen dengan media adobe flash untuk siswa SMP kelas IX dinyatakan praktis berdasarkan hasil wawancara dengan guru bidang studi bahasa Indonesia dan hasil respons siswa; dan (3) bahan ajar menulis cerpen dengan media adobe flash untuk siswa SMP kelas IX efektif meningkat-kan kemampuan siswa dalam menulis cerpen.

Produk media pembelajaran bahasa Indonesia dengan media adobe flash dapat dijadikan salah satu sumber penunjang dalam proses pembelajaran dan sebagai sumber belajar allternatif secara mandri oleh peserta didik sehingga lebih termotivasi untuk belajar. Produk bahan ajar menulis cerpen dengan media adobe flash dapat didiseminasikan pada sekolahsekolah lain di wilayah kota Balikpapan yang peserta didiknya membutuh-kan bahan ajar yang dikombinasikan dengan media untuk membantu dalam proses belajar sehingga tidak hanya di SMP 
Negeri 3 Balikpapan saja tetapi juga di Sekolah Menengah Pertama (SMP) lainnya.

Saran dari hasil penelitian ini adalah perlu dikembangkan bahan ajar menulis cerpen dengan media adobe flash dengan menggunakan media pembelajaran pada materi lain yang tidak terbatas hanya materi menulis cerpen saja. Demikian juga untuk mata pelajaran yang lain. Harapannya peserta didik mempunyai banyak sumber belajar yang dapat memotivasi siswa belajar mandiri, berpikir kreatif dan inovatif. Selain itu juga guru dapat menggunakan media pembelajaran tersebut sebagai sumber penunjang dalam proses pembelajaran serta tidak menutup kemungkinan guru dapat mengembangkan bahan ajar menjadi sebuah bahan pembelajaran bahasa Indonesia.

\section{DAFTAR PUSTAKA}

Aminuddin. (2011). Pengantar Apresiasi Karya Sastra. Bandung: Sinar Baru Algensindo

Arikunto, S. (2016). Prosedur Penelitian Suatu Pendekatan Praktik. Jakarta: Rineka Cipta.

Asyhar, R. (2011). Kreatif Mengem-bangkan Media Pembelajaran. Jakarta: Gaung Persada Press.

Borg, W. R. \& Gall, M. D. (1983). Educational Research: An Introduction, Fifth Edition. New York: Longman.

Depdiknas. (2006). Kurikulum Bahasa dan Sastra Indonesia. Bahan Latiban Terintegrasi Berbasis Kompetensi Guru SMP. Jakarta: Depdiknas

Depdiknas. (2006). Pedoman KTSP. Jakarta: Direktorat Pembinaan Sekolah Menengah Pertama

Dikse, I W. (2010). Animasi dengan Flash 8. Yogyakarta: Graha Ilmu.

Ernawati, D. K. 2012. Pengembangan Media Pembelajaran Berbasis Kuis Interaktif Berbasis Macromedia Flash. http://digilib.uin-suka.ac.id.
Hidayatullah, P. (2011). Membuat Edukatif Flash. Bandung: Informatika.

Kemendiknas. (2011). Kurikulum Bahasa dan Sastra Indonesia. Jakarta: Direktorat Pembinaan Sekolah Menengah Pertama.

Kosasih. A. \& Angkowo, R. (2007). Optimalisasi Media Pembelajaran. Jakarta: Grassindo.

Latuheru, J. D. (1988). Media Pembelajaran Dalam Proses Belajar-Mengajar Masa Kini. Jakarta: Departemen Pendidikan dan Kebudayaan.

Lestari, I. (2013). Pengembangan Bahan Ajar Berbasis Kompetensi. Padang: Akademia Permata.

Musfiqon. (2012). Pengembangan Media dan Sumber Pembelajaran. Jakarta: Prestasi Pustaka Raya.

Novian. (2005). Pengembangan Media Pembelajaran Berbasis Multimedia untuk. Mata Pelajaran Fisika Bahasan Kinematika Gerak Lurus. Semarang: Universitas Negeri Semarang.

Rohani, A. (1997). Media Instruksional Edukatif. Jakarta: Rineka Cipta.

Rokhmansyah, A. (2014). Studi dan Pengkajian Sastra. Yogyakarta: Graha Ilmu.

Sugiyono. (2014). Pengembangan Bahan Ajar Menyimak Berbasis Multimedia Interaktif dalam Model Belajar Mandiri untuk Sekolah Menengah Pertama. Seloka: Jurnal Pendidikan Bahasa dan Sastra Indonesia, 3(2), 8389.

Sugiyono. (2015). Metode Penelitian Pendidikan. Bandung: Alfabeta.

Tarigan, H. G. (2008). Membaca Sebagai Suatu Ketrampilan. Bandung: Angkasa. 
